\title{
Получение гетероструктурных оксидных композиций для перспективных солнечных элементов нового поколения
}

\author{
(C) А.А. Бобков, Н.А. Лашкова, А.И. Максимов, В.А. Мошников, С.С. Налимова
}

Санкт-Петербургский государственный электротехнический университет (ЛЭТИ), 197376 Санкт-Петербург, Россия

E-mail: darklord125@mail.ru

(Получена 21 июня 2016 г. Принята к печати 29 июня 2016 г.)

Рассматриваются перспективы создания солнечных элементов на основе оксидов металлов с объемным гетеропереходом, при этом $\mathrm{ZnO}$ был сформирован методом гидротермального синтеза. Представлены результаты синтеза наностержней оксида цинка на различных затравочных слоях. Отмечена значительная роль операции формирования зародышевого слоя. Показана возможность управления структурой массивов наностержней посредством использования поверхностно-активного вещества. Полученные ограненные наностержни перспективны для получения солнечных элементов нового поколения.

DOI: 10.21883/FTP.2017.01.43997.8356

\section{1. Введение}

Солнечная энергетика относится к наиболее перспективным возобновляемым источникам энергии. Интерес представляет развитие гибкой электроники, для которой невозможно использовать традиционные полупроводниковые гетероструктуры, так как при механическом воздействии они будут растрескиваться. Перспективным считается переход от таких гетероструктур на основе твердых растворов $\mathrm{A}^{\mathrm{III}} \mathrm{B}^{\mathrm{V}}$ к наногетероструктурам, особенно на основе оксидов. Для создания солнечных элементов широко используются полупроводниковые оксиды металлов $\left(\mathrm{TiO}_{2}, \mathrm{ZnO}, \mathrm{CuO}, \mathrm{Cu}_{2} \mathrm{O}, \mathrm{SnO}_{2}\right.$ и др.). Среди различных видов солнечных элементов, солнечные элементы на основе гетероперехода $\mathrm{ZnO} / \mathrm{CuO}$ и $\mathrm{ZnO} / \mathrm{Cu}_{2} \mathrm{O}$ представляют большой интерес, поскольку их эффективность преобразования энергии падающих фотонов в электрическую может достигать 80\% [1]. Также в работе [2] показана перспективность использования переходов $\mathrm{ZnO} / \mathrm{CuO}$. Однако для получения эффективных элементов на гетероструктурах требуется эпитаксия на определенные кристаллические грани с близкими значениями параметра кристаллической решетки.

Эффективность преобразования энергии солнечных элементов на основе гетероперехода $\mathrm{ZnO} / \mathrm{Cu}_{2} \mathrm{O}$, полученных методом магнетронного распыления, достигает $0.24 \%$ [3]. В случае планарных гетеропереходов разделение носителей заряда осуществляется только в узкой области, толщина которой находится в пределах от единиц нанометров до десятков микрометров, вблизи гетерограницы. Характеристики фотоприемных гетероструктур могут быть улучшены при использовании преимуществ наногетеропереходов. Фотовольтаические устройства на основе нановолокон $\mathrm{ZnO}$, полученных методом electrospun, и электроосажденного слоя $\mathrm{Cu}_{2} \mathrm{O}$ проявляют эффективность преобразования энергии $\sim 0.77 \%$ [4]. Трехмерные упорядоченные структуры $\mathrm{Al}-\mathrm{ZnO}-\mathrm{ZnO} / \mathrm{Cu}_{2} \mathrm{O}$ на основе массивов нанопроводов $\mathrm{ZnO}$ и электроосажденных слоев $\mathrm{Cu}_{2} \mathrm{O}$ имеют максимальную эффективность $1.52 \%$ [5].
Особенностью гетероперехода является требование бездефектных стыковок кристаллических решеток, возможное лишь при совпадении типа, ориентации и периода кристаллических решеток сращиваемых материалов, и которое позволяет существенно уменьшить плотность электронных состояний на интерфейсе. Для неразрывного продолжения решетки одного вещества другим в принципе достаточно, чтобы хотя бы одна из граней каждой решетки имела близкие геометрические параметры. Для улучшения характеристик солнечных элементов на гетеропереходе $\mathrm{ZnO} / \mathrm{CuO}$ возможно использование одномерных структур $\mathrm{ZnO}$ вместо тонкого слоя. Таким образом, достигается возрастание удельной площади контакта гетероперехода, которая может быть увеличена в сотни раз [6].

В соответствии с особенностями кристаллических модификаций оксидов меди (моноклинная, $a=0.4684$ нм, $b=0.3425$ нм, $c=0.5129$ нм) и цинка (гексагональная, $a=0.3249 \mathrm{Hм}, c=0.5206 \mathrm{Hм}$ ) и, учитывая рассогласование параметров кристаллических решеток, существует возможность создания практически бездефектного гетероперехода. При этом необходимо осуществить ориентированный рост слоев оксида меди нанометровой толщины на поверхности естественно ограненных кристаллов оксида цинка, т. е. совместить грань (100) $\mathrm{CuO}$ с гранью (10-10) $\mathrm{ZnO}$.

Интересной тенденцией является использование фрактальных $p-n$-переходов [7,8]. Идея „объемного гетероперехода“ может позволить в структурах на основе неорганических полупроводников увеличить площадь гетероконтакта на несколько порядков, что увеличит вероятность поглощения кванта света вблизи гетероперехода в такое же количество раз. Такое свойство границы раздела фаз используется при формировании суперконденсаторных структур с применением полимерных фрактальных границ. При „фрактальной гетерогранице“ на электроды замыкаются разные фазы, но контакт между ними происходит практически по всему объему активного слоя. Две фазы с различной электропроводностью (ионной и электронной в суперконденсаторах; 
$p$ - и $n$-типа электропроводности в $p-n$-переходах) проникают друг в друга и формируют высокую площадь гетероконтакта с образованием двойного электрического слоя. Все эти задачи принципиально могут быть решены при использовании технологических приемов, обеспечивающих рост одномерных структур. При этом первоначально должны получаться ограненные наноструктуры оксида цинка, эффективно заполняющие пространство и обеспечивающие высокую площадь контакта $\mathrm{ZnO} / \mathrm{CuO}$.

Объемный гетеропереход в перспективных солнечных элементах на основе $\mathrm{ZnO} / \mathrm{CuO}$ может быть сформирован при использовании одномерных нанообъектов оксида цинка, при этом требование упорядоченности массивов одномерных нанообъектов не является необходимым. Оксид цинка обладает электропроводностью $n$-типа. Образование слоя $p$-типа электропроводности достигается осаждением слоя оксида меди, полностью заполняющего пространство между одномерными объектами оксида цинка с образованием контакта с токосъемным электродом.

Цель настоящей работы состоит в изучении особенностей возникновения одномерных наноструктур с формированием зародышевого слоя и условий выращивания ограненных стержней $\mathrm{ZnO}$.

Одномерные наноструктуры оксида цинка могут быть получены растворными методами $[9,10]$. В общем $\mathrm{ZnO}$ формируется в результате гидролиза и конденсации соли цинка в щелочной среде [11]. Как правило, в качестве прекурсора оксида цинка используют такие неорганические соединения, как нитрат цинка $\mathrm{Zn}\left(\mathrm{NO}_{3}\right)_{2}$, и органические, ацетат цинка $\mathrm{Zn}\left(\mathrm{O}_{2} \mathrm{C}_{2} \mathrm{H}_{3}\right)_{2}$. В качестве основания, как правило, используют $\mathrm{NaOH}, \mathrm{KOH}$, $\mathrm{NH}_{4} \mathrm{OH}$, гидроксид аммония или гексаметилентетрамин $\mathrm{C}_{6} \mathrm{H}_{12} \mathrm{~N}_{4}$. В ходе реакции прекурсор цинка гидролизуется, в результате чего появляются ионы $\mathrm{Zn}^{2+}$, которые реагируют с анионами основания $\mathrm{OH}^{-}$(уравнение (1)). В ходе реакции могут сформироваться различные гидроксиды, в том числе $\mathrm{ZnOH}^{+}$(водный), $\mathrm{Zn}(\mathrm{OH})_{2}$ (водный $), \mathrm{Zn}(\mathrm{OH})_{2}, \mathrm{Zn}(\mathrm{OH})^{3-}$ (водный $)$ и $\left[\mathrm{Zn}(\mathrm{OH})_{4}\right]^{2-}$. Затем промежуточные гидроксиды конденсируются в виде оксида (уравнение (2)) [12]:

$$
\begin{gathered}
\mathrm{Zn}^{2+}+\mathrm{OH}^{-} \leftrightarrow[\mathrm{Zn}(\mathrm{OH})]^{+}, \\
\mathrm{Zn}^{2+}+2 \mathrm{OH}^{-} \leftrightarrow \mathrm{Zn}(\mathrm{OH})_{2}, \\
\mathrm{Zn}^{2+}+3 \mathrm{OH}^{-} \leftrightarrow\left[\mathrm{Zn}(\mathrm{OH})_{3}\right]^{-}, \\
\mathrm{Zn}^{2+}+4 \mathrm{OH}^{-} \leftrightarrow\left[\mathrm{Zn}(\mathrm{OH})_{4}\right]^{2-}, \\
{\left[\mathrm{Zn}(\mathrm{OH})_{4}\right]^{2-} \leftrightarrow \mathrm{ZnO}+\mathrm{H}_{2} \mathrm{O}+2 \mathrm{OH}^{-} .}
\end{gathered}
$$

Общая химическая реакция может быть записана:

$$
\mathrm{Zn}^{2+}+2 \mathrm{OH}^{-} \leftrightarrow \mathrm{ZnO}+\mathrm{H}_{2} \mathrm{O} .
$$

Следует отметить, что с точки зрения формирования одномерных структур на основе оксида цинка уравнение (1.2) не может быть использовано, так как в результате его протекания образуется незаряженный гидроксид цинка. Заряженные продукты реакции 1 могут адсорбироваться на различные заряженные грани растущих структур или кристаллитов зародышевого слоя.
Данные химические реакции, как правило, являются равновесными в водных растворах и имеют тенденцию протекать в направлении минимизации свободной энергии всей системы. Наиболее высокоэнергетическими поверхностями оксида цинка являются полярные плоскости (0001), которые заканчиваются либо ионами $\mathrm{Zn}^{2+}$, либо ионами $\mathrm{O}^{2-}$. Поэтому адсорбция новых молекул, образовавшихся в результате гидролиза прекурсора, происходит на этих полюсных плоскостях из соображений минимизации поверхностной энергии. В частности, адсорбция молекул происходит за счет образования монослоя, имеющего противоположную полярность уже существующей плоскости (0001). Таким образом, на поверхность, завершенную атомами $\mathrm{Zn}^{2+}$, осаждается $\mathrm{O}^{2-}$ и образуется плоскость, завершенная $\mathrm{O}^{2-}$. Поэтому рост микро- и наноструктур оксида цинка происходит в направлении оси $c$, что приводит к образованию анизотропной структуры.

\section{2. Эксперимент}

В данной работе синтез одномерных структур на основе оксида цинка проводился гидротермальным методом. Исходя из того, что протекание реакции $\mathrm{Zn}(\mathrm{OH})_{2} \leftrightarrow \mathrm{ZnO}+\mathrm{H}_{2} \mathrm{O}$ происходит при температурах выше $80^{\circ} \mathrm{C}$, была выбрана температура синтеза, составляющая $85^{\circ} \mathrm{C}$. Реакции, протекающие при гидротермальном синтезе нитевидных нанокристаллов $\mathrm{ZnO}$, приведены далее:

$$
\begin{aligned}
& \mathrm{C}_{6} \mathrm{H}_{12} \mathrm{~N}_{4}+6 \mathrm{H}_{2} \mathrm{O} \leftrightarrow 4 \mathrm{NH}_{3}+6 \mathrm{HCHO}, \\
& \mathrm{NH}_{3}+\mathrm{H}_{2} \mathrm{O} \leftrightarrow \mathrm{NH}^{4+}+\mathrm{OH}^{-}, \\
& \mathrm{Zn}^{2+}+4 \mathrm{NH}_{3} \leftrightarrow\left[\mathrm{Zn}\left(\mathrm{NH}_{3}\right)_{4}\right]^{2+} \\
& \mathrm{Zn}^{2+}+2 \mathrm{OH}^{-} \leftrightarrow \mathrm{Zn}(\mathrm{OH})_{2}, \\
& \mathrm{Zn}(\mathrm{OH})_{2} \leftrightarrow \mathrm{ZnO}+\mathrm{H}_{2} \mathrm{O} .
\end{aligned}
$$

В качестве раствора для гидротермального синтеза используются эквимолярные растворы нитрата или ацетата цинка в качестве источника ионов $\mathrm{Zn}^{2+}$ и гексаметилтетрамина. Для модификации растворов и создания условий ограничения роста диаметра одномерных объектов использовали поверхностно-активное вещество СТАВ. После синтеза полученные образцы промывались дистиллированной водой.

Важным этапом создания одномерных структур ZnO является создание зародышевого слоя. В данной работе использовались три варианта зародышевого слоя.

Первым типом зародышевого слоя являлся поликристаллический подслой оксида цинка, сформированный методом спрей-пиролиза. Основные технологические особенности синтеза и их влияние на структуру слоя приведены в $[13,14]$. На нагревательном элементе расположены подложки, на которые при помощи пневматического аэрографа происходит распыление жидких растворов. Газ-носитель (воздух) подается при помощи компрессора через фильтр и регулятор давления. Распы- 
ляемый раствор поступает из делительной воронки объемом 250 мл. Расстояние $L$ от сопла аэрографа до подложек изменяли в диапазоне от 15 до 30 см. В качестве распыляемого раствора был использован раствор ацетата цинка $\mathrm{Zn}\left(\mathrm{CH}_{3} \mathrm{COO}\right)_{2} \cdot 2 \mathrm{H}_{2} \mathrm{O}$ с концентрацией 0.1 моль/л. Состав растворителя представляет собой смесь воды и изопропилового спирта в объемном соотношении $1: 3$. Для полного растворения использовалась уксусная кислота, доля которой составляла 0.01 от общего объема смеси. Температура подложки составляла $380^{\circ} \mathrm{C}$. Давление устанавливалось 1.4 бара, при этом наблюдался наиболее однородный поток распыляемого раствора. Время синтеза варьировалось от 30 с до 40 мин. Далее полученные слои $\mathrm{ZnO}$ подвергались отжигу в муфельной печи.

Вторым вариантом затравочного слоя был выбран слой наночастиц $\mathrm{ZnO}$, нанесенный методом центрифугирования. Для получения наночастиц оксида цинка готовили растворы гидроксида натрия и ацетата цинка в изопропаноле. Полученные растворы смешивали на магнитной мешалке, с добавлением поливинилпиролидона для стабилизации роста частиц. Скорость центрифугирования составляла 3000 об/мин. Зародышевый слой подвергался отжигу при температуре $T=550^{\circ} \mathrm{C}$ в течение 30 мин.

В качестве третьего типа зародышевого слоя использовались нанокомпозиты $\mathrm{ZnO}-\mathrm{SiO}_{2}$, полученные зольгель технологией [15-20]. Прекурсоры, хлорид цинка $\mathrm{ZnCl}_{2}$ и тетраэтоксисилан (ТЭОС) $\mathrm{Si}\left(\mathrm{OC}_{2} \mathrm{H}_{5}\right)_{4}$, растворяли в изопропиловом спирте. В зависимости от соотношения исходных компонентов получены растворы различного состава. Полученный раствор наносили на подложки центрифугированием (3000 об/мин, 30 с). Отжиг проводили при $500^{\circ} \mathrm{C}$ в течение 30 мин.

В качестве методов исследования использовали растровую электронную микроскопию (РЭМ TESCAN MIRA LMU) и оптическую спектроскопию (спектрофотометр видимого и ультрафиолетового диапазонов ПЭ-5400 УФ).

\section{3. Результаты и обсуждение}

На рис. 1 приведены спектры оптической плотности зародышевых слоев оксида цинка, полученных методом спрей-пиролиза при различном времени синтеза, которые свидетельствуют о завершении всех химических процессов с образованием кристаллической структуры оксида цинка. По результатам исследований определен край собственного поглощения оксида цинка, который составляет 370 нм. Край собственного поглощения проявляется на спектрах всех образцов, время синтеза которых превышает 15 мин. Данные результаты позволяют утверждать, что сплошной кристаллический слой оксида цинка на поверхности подложек образуется при временах синтеза больше 15 мин.

Это является одной из важных задач при формировании солнечных элементов, так как при создании их излучение вводится в сформированную структуру через

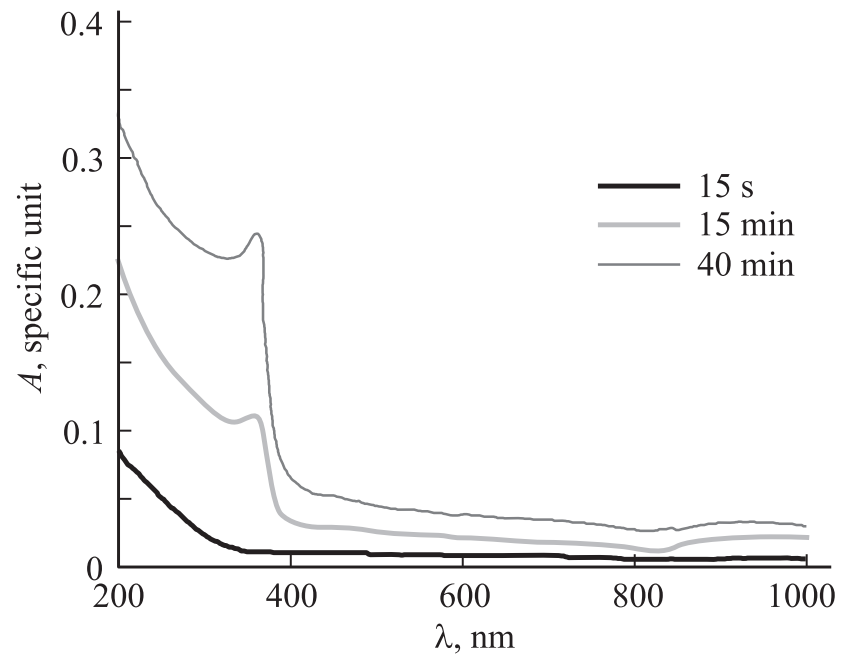

Рис. 1. Спектры оптической плотности зародышевых слоев $\mathrm{ZnO}$, полученных методом спрей-пиролиза.

широкозонное окно, чем и может служить сформированная методом спрей-пиролиза пленка оксида цинка.

Впоследствии на зародышевом слое, полученном методом спрей-пиролиза, производился рост нанопроводов оксида цинка. По данным растровой электронной микроскопии было установлено, что формирование нитевидных кристаллов объединены в конгломераты, находящиеся на поверхности подложки без адгезионной связи с ней.

При этом размеры одномерных нанокристаллов, имеющих гексагональную огранку, лежат в широком диапазоне. Длина варьируется от долей до единиц микрона, а ширина варьируется от десятков до сотен нанометров.

Использование подслоя из наночастиц $\mathrm{ZnO}$, нанесенного методом центрифугирования, позволяет получать массивы одномерных нанокристаллов оксида цинка (рис. 2). Выращенные кристаллы однородны по размерам и имеют гексагональную огранку. Поперечное сечение нанокристаллов составляет около 50 нм, а длина около микрона.

Следует отметить, что при подобном формировании зародышевого слоя растущие при проведении гидротермального синтеза одномерные объекты оксида цинка адгезионно прочно соединены с подложкой, так как кристаллы затравочного слоя закрепляются на поверхности в процессе термообработки.

На рис. 3 показаны наностержни оксида цинка, выращенные на подслое, представляющем собой нанокомпозит $80 \% \mathrm{ZnO}-20 \% \mathrm{SiO}_{2}$. Также в рамках эксперимента было проанализировано влияние ПАВ на структуру полученных гидротермальным синтезом образцов. Анализ образцов проводился методом РЭМ, микрофотографии приведены на рис. 4, 5.

Было замечено, что использование ростового раствора, содержащего поверхностно-активное вещество СТАВ, приводит к образованию в растворе ограненных кристаллов $\mathrm{ZnO}$ размером порядка нескольких микрометров (рис. 5). 


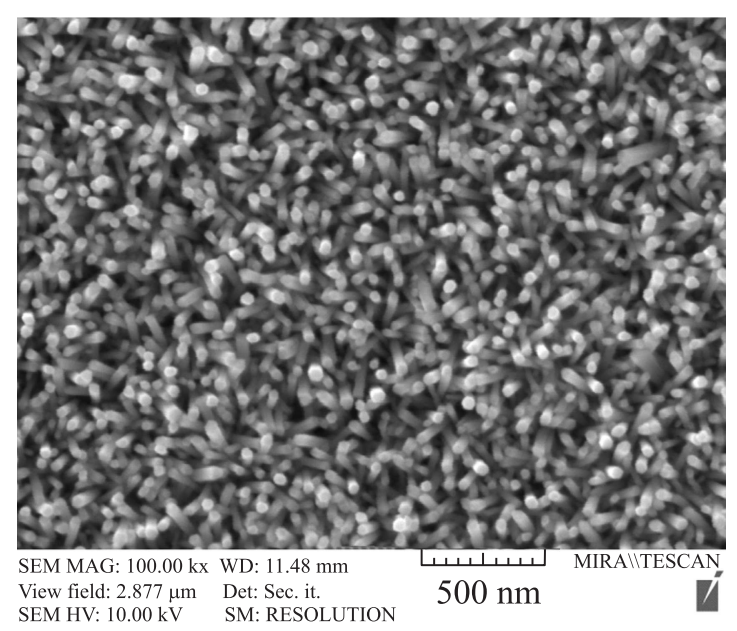

Рис. 2. Наностержни оксида цинка на зародышевом слое из наночастиц $\mathrm{ZnO}$, нанесенных методом центрифугирования.

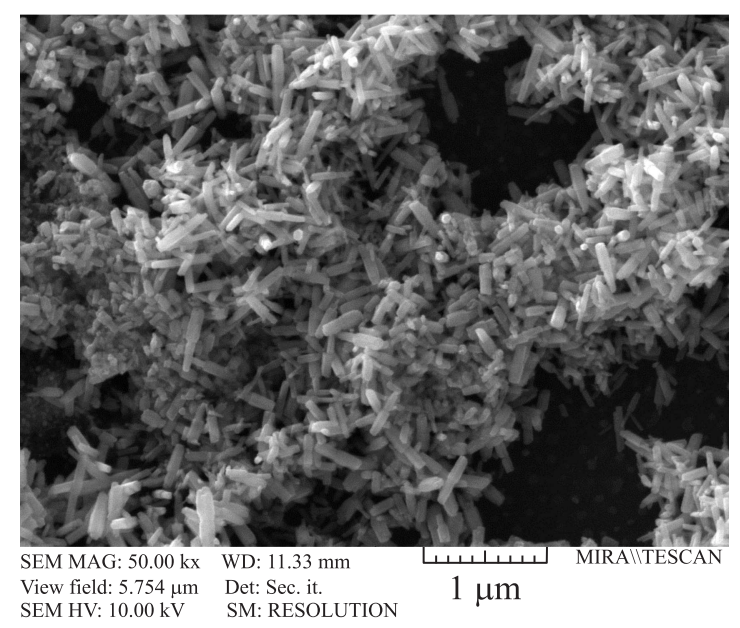

Рис. 3. Наностержни оксида цинка на зародышевом слое состава $80 \% \mathrm{ZnO}-20 \% \mathrm{SiO}_{2}$.

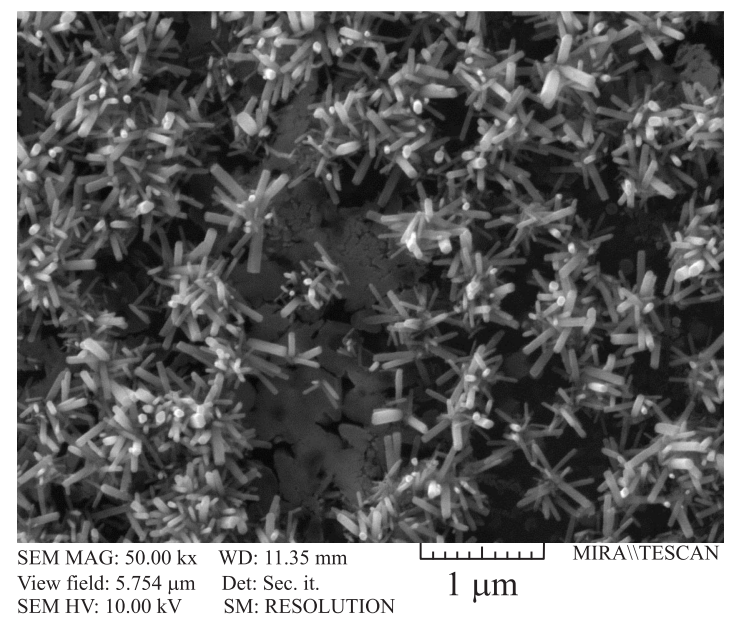

Pис. 4. Микрофотографии наностержней оксида цинка, выращенных с добавлением СТАВ на подслое, представляющем собой нанокомпозит $80 \% \mathrm{ZnO}-20 \% \mathrm{SiO}_{2}$.
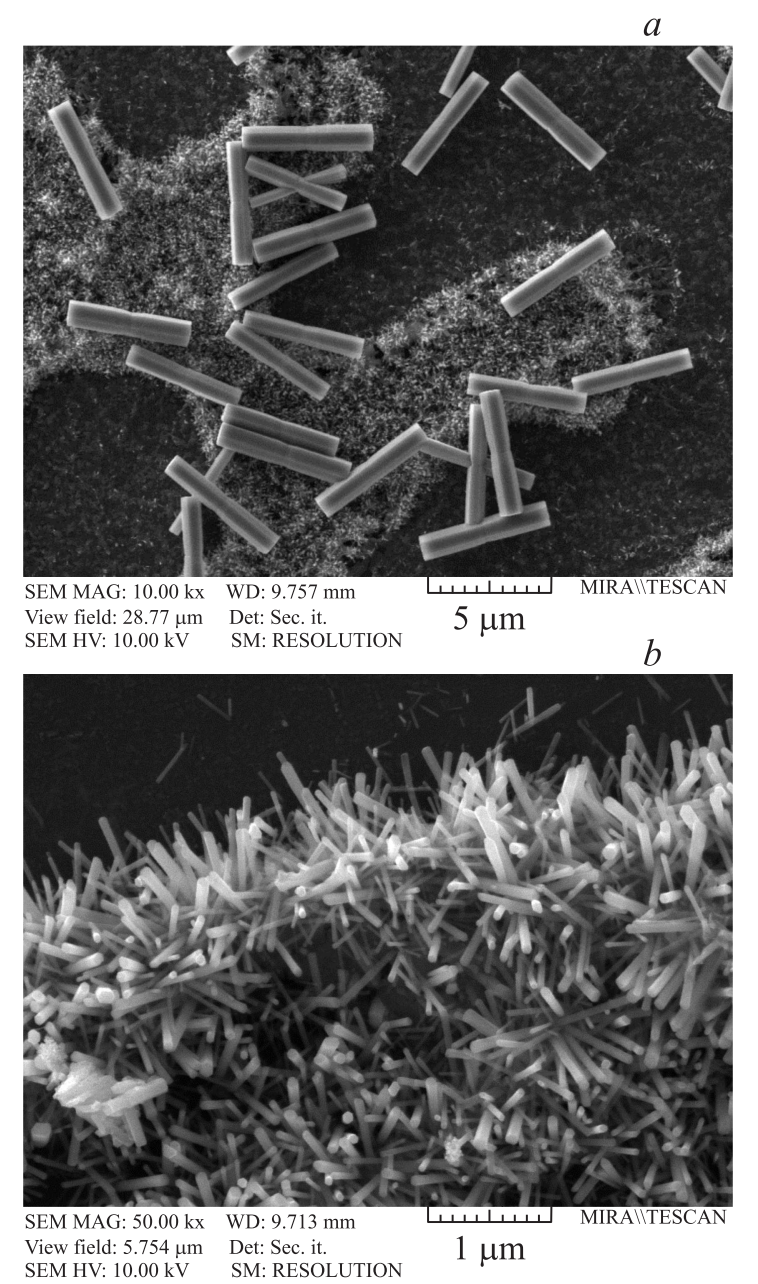

Рис. 5. $a-$ микрофотографии наностержней оксида цинка, выращенных из раствора с добавлением СТАВ на подслое, представляющем собой нанокомпозит $90 \% \mathrm{ZnO}-10 \% \mathrm{SiO}_{2}$. $b$ - микрофотографии наностержней оксида цинка, выращенных из раствора с добавлением СТАВ на подслое, представляющем собой нанокомпозит $90 \% \mathrm{ZnO}-10 \% \mathrm{SiO}_{2}$.

На рис. 5, $a$ и $b$ приведены различные формы нанокристаллов оксида цинка, сформировавшиеся в объеме раствора и осажденные на поверхность подложки по окончании процесса синтеза массивов одномерных структур на поверхности. Как видно из приведенных рисунков, в растворе способны сформироваться как удлиненные стержни, так и пространственные объекты „ежи“. Недостатком таких объектов для использования в солнечных элементах является недостаточная механическая и электрическая связь с подложкой.

Анализ микрофотографий, приведенных на рис. 4, показывает, что применение поверхностно-активного вещества при создании раствора для роста наностержней приводит к уменьшению диаметра растущих наностержней при увеличении их длины. При этом дисперсия по поперечным размерам стержней составляет 30-100 и 30-60 нм в образцах, приготовленных без применения и с применением СТАВ соответственно. Применение 
нанокомпозита $80 \% \mathrm{ZnO}-20 \% \mathrm{SiO}_{2}$ в качестве затравочного слоя стимулирует рост пучков наностержней различного диаметра вблизи одного центра роста (hedgehog-like).

В отличие от этого, применение нанокомпозита $90 \%$ $\mathrm{ZnO}-10 \% \mathrm{SiO}_{2}$ для роста наностержней в присутствии СТАВ приводит к росту слабоупорядоченных массивов наностержней в локальных областях подложки (рис. $5, a, b)$. Поперечные размеры наностержней в массивах находятся в диапазоне от 30 до 60 нм. Следует отметить, что на поверхности таких образцов наблюдаются стержни большого диаметра, образовавшиеся в растворе и выпавшие на поверхность. Диаметр таких стержней изменяется в пределах $0.5-1$ мкм (рис. 5, $a$ ). Проведение процессов роста наностержней оксида цинка при отсутствии СТАВ на нанокомпозите $90 \% \mathrm{ZnO}-10 \%$ $\mathrm{SiO}_{2}$ в качестве зародышевого слоя приводит к появлению малого количества наностержней, горизонтально расположенных к поверхности подложки, и полному отсутствию упорядоченности структуры.

\section{4. Заключение}

Как было показано, использование зародышевого слоя, полученного методом спрей-пиролиза, не позволяет формировать массивы одномерных нанокристаллов, имеющих механическую связь с подложкой. В то же время синтез на зародышевом слое из наночастиц позволяет получать одномерные нанокристаллы в виде массивов, которые могут применяться в качестве широкозонного полупроводника в так называемом „объемном гетеропереходе“ $n-\mathrm{ZnO} / p-\mathrm{CuO}$. Зародышевый слой, полученный золь-гель методом, также позволяет получать массивы наностержней, при этом упорядоченность роста одномерных объектов в этих массивах частично отсутствует. Увеличение степени упорядоченности массивов наностержней может быть достигнуто использованием поверхностно-активного вещества. Следовательно, гидротермальный синтез одномерных нанокристаллов $\mathrm{ZnO}$ на зародышевом слое из наночастиц $\mathrm{ZnO}$ может являться одним из основных технологических этапов создания фотовольтаических элементов нового поколения.

Работа выполнена за счет гранта Российского научного фонда (проект № 14-12-00327).

\section{Список литературы}

[1] M.Z. Sahdan, M.F. Nurfazliana, S.A. Kamaruddin, Z. Embong, Z. Ahmad, H. Saim. Procedia Manufacturing, 2, 379 (2015).

[2] Ш.Р. Адилов, М.Е. Кумеков, С.Е. Кумеков, Е.И. Теруков. ФТП, 47 (5), 642 (2013).

[3] S. Noda, H. Shima, H. Akinaga. J. Phys. Conf. Ser., 433, 012 (2013).

[4] Luming Zhang, Huaquan Sun, Lai Xie, Jinnan Lu, Luyong Zhang, Sujuan Wu, Xingsen Gao, Xubing Lu, Jinhua Li, Jun-Ming Liu. Nanoscale Res. Lett., 10, 465 (2015).
[5] X. Chen, P. Lin, X. Yan, Z. Bai, H. Yuan, Y. Shen, Y. Liu, G. Zhang, Z. Zhang, Y. Zhang. ACS Appl. Mater. Interfaces, 7, 3216 (2015).

[6] Т.В. Пешкова, Д.Ц. Димитров, С.С. Налимова, И.Е. Кононова, Н.К. Николаев, К.И. Папазова, А.С. Божинова, В.А. Мошноков, Е.И. Теруков. ЖТФ, 84 (5), 143 (2014).

[7] С.Ф. Мусихин, В.И. Ильин, Т.А. Гаврикова, М.А. Васильева. Науч.-техн. ведомости СПбГПУ, 2 (170), 212 (2013).

[8] С.Ф. Мусихин, В.И. Ильин. Науч-техн. ведомости СПбГПУ, вып. 4, 105 (2007).

[9] С.Ф. Мусихин, В.И. Ильин. Науч.-техн. ведомости СПбГПУ, 3, 183 (2008).

[10] I.A. Pronin, I.A. Averin, N.D. Yakushova, D.T. Dimitrov, L.K. Krasteva, K.I. Papazova, A.S. Chanachev, A.S. Bojinova, A.T. Georgieva, V.A. Moshnikov. Sensors Actuators A: Physical., 206, 88 (2014).

[11] А.А. Бобков, А.И. Максимов, В.А. Мошников, П.А. Сомов, Е.И. Теруков. ФТП, 49 (10), 1402 (2015).

[12] S.S. Karpova, V.A. Moshnikov, A.I. Maksimov, S.V. Mjakin, N.E. Kazantseva. Semiconductors, 47 (8), 1026 (2013).

[13] Sheng Xu, Zhong Lin Wang. Nano Res., 4 (11), 1013 (2011).

[14] Н.А. Лашкова, А.И. Максимов, Л.Б. Матюшкин, В.А. Мошников, А.А. Рябко, П.А. Сомов, С.С. Туленин. Бутлеровские сообщения, 42 (6), 48 (2015).

[15] N.A. Lashkova, N.V. Permiakov, A.I. Maximov, Y.M. Spivak, V.A. Moshnikov. St. Petersburg Polytechnical University Journal: Physics and Mathematics, 1 (1), 15 (2015).

[16] I.E. Gracheva, V.A. Moshnikov, E.V. Maraeva, S.S. Karpova, O.A. Alexsandrova, N.I. Alekseyev, V.V. Kuznetsov, K.N. Semenov, A.V. Startseva, A.V. Sitnikov, G. Olchowik, J.M. Olchowik. J. Non-Cryst. Sol., 358 (2), 433 (2012).

[17] V.A. Moshnikov, I.E. Gracheva, V.V. Kuznezov, A.I. Maximov, S.S. Karpova, A.A. Ponomareva. J. Non-Cryst. Sol., 356 (37-40), 2020 (2010).

[18] V.S. Levitskii, A.I. Maksimov, V.A. Moshnikov, E.I. Terukov. Phys. Sol. St., 56 (2), 270 (2014).

[19] Н.А. Лашкова, А.И. Максимов, А.А. Рябко, А.А. Бобков, В.А. Мошников, Е.И. Теруков. ФТП, 50 (9), 1276 (2016).

[20] A.A. Ponomareva, V.A. Moshnikov, O.A. Maslova, Yu.I. Yuzyuk, G. Suchaneck. Glass Phys. and Chem., 40 (1), 99 (2014).

[21] E.V. Abrashova, I.E. Gracheva, V.A. Moshnikov. J. Phys. Conf. Ser., 461, 012019 (2013).

Редактор Г.А. Оганесян

\section{Obtaining heterostructure compositions from oxide for perspective solar cells of new generation}

\section{A.A. Bobkov, N.A. Lashkova, A.I. Maximov, V.A. Moshnikov, S.S. Nalimova}

St. Petersburg Electrotechnical University „LETI“, 197376 St. Petersburg, Russia

Abstract In this paper describes the prospects for the creation of solar cells based on metal oxides. The hydrothermal synthesis was used. Results of synthesis nanorods zinc oxide from different seed layers was shown. A significant role of skin-layer for nanocrystal formation was noted. The ability to control the structure of arrays nanorods through the use of surface-active substances was shown. These faceted nanorods are promising for solar cells of oxide heterostructures. 